Keywords:

Baccharis platypoda

Asteraceae

Reproductive phenology

Vegetative phenology

Dioecious

Seasonality

Historic:

Received 22/06/2017

Accepted 06/12/2017

Palavras chave: Baccharis platypoda

Asteraceae

Fenologia reprodutiva

Fenologia vegetativa

Dioicia

Sazonalidade

+Correspondence: darliana.fonseca@ufvjm.edu.br
Darliana Costa Fonseca' ${ }^{1+}$, Márcio Leles Romarco Oliveira', Israel Marinho Pereira', Cássia Michelle Cabral', Cristiane Coelho Moura', Evandro Luiz Mendonça Machado'

\section{PHENOLOGICAL STRATEGIES OF DIOECIOUS SPECIES IN RESPONSE TO THE ENVIRONMENTAL VARIATIONS OF RUPESTRIAN GRASSLANDS}

ABSTRACT: Rupestrian grasslands present great diversity of phenological patterns in response to the high biodiversity of this ecosystem and its environmental variation. Dioecious species show distinction between the genders in relation to the nutritional requirements for growth and reproduction, comprehending determining factors, especially in restrictive environments. The purpose of the study was to comprehend the reproductive and vegetative phenology of the dioecious species Baccharis playtypoda, joining the phenological strategies with the sexual system and the environment seasonal variations. The study was performed in three areas of rupestrian grassland, where the phenology of thirty plants from September/20I0 through September/20II was observed. The Fournier intensity method, Spearman's correlation and circular analysis were used. The reproductive phenophases began in February and ended between September and October, while the vegetative phenophases presented intensity variation during that period. The vegetative phenophases of both genders has shown low seasonal standard, while the reproductive phenophases has presented strong seasonality. The species B. platypoda has presented little variations in the phenological strategies of male and female individuals, mainly during the reproductive phenophases and in the vegetative growth for the allocation of resources. The species' reproductive phenology had been associated to some environmental variables, mainly for the fructification phenophases, while the vegetative phenology, in general, had been most associated to the reproductive phenology of the species.

\section{ESTRATÉGIAS FENOLÓGICAS DE ESPÉCIES DIOICAS EM RESPOSTA A VARIAÇÕES AMBIENTAIS DOS COMPLEXOS RUPESTRES}

RESUMO: Complexos rupestres apresentam uma grande diversidade de padrões fenológicos como resposta à alta biodiversidade deste ecossistema e sua variação ambiental. Espécies dioicas apresentam distinção entre os sexos quanto às exigências nutricionais para crescimento e reprodução, compreendendo fatores determinantes na variação da fenologia reprodutiva e vegetativa, principalmente em ambientes restritivos. $O$ estudo objetivou compreender a fenologia reprodutiva e vegetativa da espécie dioica Baccharis platypoda, associando as estratégias fenológicas ao sistema sexual e às variações sazonais do ambiente. $O$ estudo foi realizado em três áreas de campo rupestre, onde foi observada a fenologia de trinta plantas, entre setembro/20 I 0 e setembro/20I I. Foram aplicados o método de intensidade de Fournier, correlação de Spearman e análise circular. As fenofases reprodutivas tiveram início no mês de fevereiro com encerramento entre setembro e outubro, enquanto que as fenofases vegetativas apresentaram variações de intensidade ao longo desse período. As fenofases vegetativas de ambos os sexos apresentaram baixo padrão sazonal, enquanto que as fenofases reprodutivas apresentaram forte sazonalidade. A espécie B. platypoda apresentou pequenas variações nas estratégias fenológicas de indivíduos masculinos e femininos, principalmente na duração das fenofases reprodutivas e no crescimento vegetativo para alocação de recursos. A fenologia reprodutiva da espécie esteve associada a algumas variáveis ambientais, principalmente para as fenofases de frutificação, enquanto que a fenologia vegetativa, de modo geral, esteve mais associada à fenologia reprodutiva das espécies.

Federal University of the Jequitinhonha and Mucuri Valleys - Diamantina, Minas Gerais, Brazil 


\section{INTRODUCTION}

The vegetal species phenology is constantly being associated to the environmental variables when determining the reproductive and vegetative events (DIAS; OLIVEIRA-FILHO, 1996; BATALHA et al., 1997; LENZA; KLINK, 2006; TOOKE; BATTEY, 20I0; TORRES; GALETTO, 20II; SEGHIERI et al., 2012; CHAURASIA; SHUKLA, 2016). The adaptation of the species when relating the life cycle and the reproductive success to the availability of resources in time and space avoids the competition and guarantees an efficient use of resources (LENZA; KLINK, 2006; OLIVEIRA, 2008). The seasonality is associated only to the need of resources allocation in specific periods of the reproductive cycle (OLIVEIRA, 2008; TORRES; GALETTO, 20I I).

The dioecious species have presented distinction between the genders in relation to the nutritional requirements necessary for its growth and reproduction (BAWA, 1980; MATSUYAMA; SAKIMOTO, 2008). Female plants may present variation in the flowering quality because of its sensibility to the punctual environmental variations (THOMAS; LAFRANKIE, 1993), showing that there are differences in the allocation of resources between male and female individuals (BULLOCK et al., 1983; THOMAS; LAFRANKIE, 1993). In other situations, the differences are only found in the responses in the reproductive process (MATSUYAMA; SAKIMOTO, 2008).

Sexual differences in the reproductive cycle can be evolutionary answers to the success in the search by the opposite sex (GRANT, 1995). Those differences represent determining factors in the variation among the reproductive phenophases standards for the dioecious species (LENZA; OLIVEIRA, 2005; 2006; AMORIM; OLIVEIRA, 2006; OTÁROLA et al., 20I3). They are results of the adaptations of the plants of different genders to the environmental conditions which favor the pollination (SUTHERLAND; DELPH, 1984; LENZA; OLIVEIRA, 2006) as greater flowering period and differences in the quantity of flowers in disposition of pollinizers (BAWA, 1990; BULLOCK; BAWA, 198I; THOMAS; LAFRANKIE, 1993; MUNGUIAROSAS et al., 2011; OTÁROLA et al., 2013; MATSUHISA; USHIMARU, 2015). The same thing occurs with the vegetative growth among different genders individuals. Some species show difference between genders in relation to the period and intensity of the vegetative phenology (SAKAI; BURRIS, 1985; MATSUYAMA; SAKIMOTO, 2008) while others showed similar gender standards (MATSUYAMA; SAKIMOTO, 2008).

The rupestrian grasslands are mosaics of vegetation formations, occurring above $900 \mathrm{~m}$ altitude with occurrence of rocky outcrops (VASCONCELOS, 20II; BORGES et al., 20II; SILVEIRA et al., 2015) associated with shallow, sandy and poor quartzite soils in nutrients, often found in the extension of the Espinhaço Range (VASCONCELOS, 20II; MESSIAS et al., 20I3; LE STRADIC et al., 2015; SILVEIRA et al., 2015). In this environment, plants are under stressful conditions due to strong solar radiation, abrupt temperature variations, intense and constant winds and a prolonged water deficit in the dry season (SILVEIRA et al., 2015). Under these unhealthy conditions, the plant species from these areas present physiological and morphological adaptations that allow them to survive the extreme conditions, which secures the existence of high levels of endemism (GASTAUER et al., 20 I2; LE STRADIC et al., 2015; SILVEIRA et al., 2015; FERNANDES, 2016). However, this rich and unique ecosystem suffers from the constant anthropogenic threats that threaten to reduce all the existing biodiversity in the rocky regions (FERNANDES et al, 20I4; LE STRADIC et al., 20 I5; SILVEIRA et al., 20I5).

The rupestrian fields are rich in herbaceous and shrub species (VASCONCELOS, 2011; ALVES et al., 20I4; SILVEIRA et al., 20I5), and have a low frequency of tree species, with families as Asteraceae, Cyperaceae, Eriocaulaceae, Melastomataceae, Poaceae and Xyridaceae (CONCEIÇÃO et al., 2007; BORGES et al., 20I I; MESSIAS et al., 20I I; GASTAUER et al., 2012; SILVEIRA et al., 20I5), the richest and most numerous in this ecosystem. Therefore, studies about dioecious species in areas of rupestrian grasslands are scarce, since this sexual system is associated to perennial, woody species occurring in tropical forest areas, presenting small opaque flowers and the production of fleshy fruits.

The dioecious species population phenology study shows a studies source on the spatial and temporal segregation of the reproductive and vegetative cycles of different gender individuals in relation to other vegetal populations, granting the productive success of the species in the resources competition. Considering that dioecious species represent about I/4 of all the life forms and that those values can be higher in taxons yet poorly studied (BAWA, 1980), it is necessary to correlate the phenological standards with the vegetal species genders under seasonal environmental variations, which is characteristic of rupestrian grassland areas.

Thus, the objective of the present study was to describe the reproductive and vegetative phenology associating the reproductive strategies to the dioecious sexual system and to the environment seasonal variations. In this sense, the following questions were tried to be answered: I). Does the species show different phenological 
strategies between the genders? II). Do the phenophases show correlation with the climatic seasonality?

\section{MATERIAL AND METHODS}

\section{Study area}

The study took place in areas next to "Córrego do Soberbo" (Soberbo stream), at $18^{\circ}$ II' $50.4^{\prime \prime} \mathrm{S}$ and $18^{\circ}$

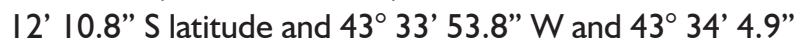
W longitude, in JK Campus, of the Federal University of Jequitinhonha and Mucuri Valleys (UFVJM) in Diamantina - MG, where the humid fields and rupestrian grassland were found.

The climate in the area is Cwb type, according to the Köppen classification, having dry winter from June through August, and rainy summer from November through March, with transition periods from April through October. During the rainy period, the average rainfall is $216.34 \mathrm{~mm}$, and the annual average 1404.7 mm (INMET, 20I2), similar to the described pattern for rupestrian field areas, with annual rainfall varying between 800 and $1500 \mathrm{~mm}$ and the dry season with an average duration of two months (ALVES et al., 20l4). The climate in the area shows average temperatures between $18^{\circ} \mathrm{C}$ and $20^{\circ} \mathrm{C}$ : higher temperatures were recorded in December and January, and lower temperatures in June and July (NEVES et al., 2005). During the phenology observation period, the months November and December 2010 and March 20II have shown higher level of rainfall than the one observed for the previous years, when the months from March to September were the driest (INMET, 20I2) (Figure I).

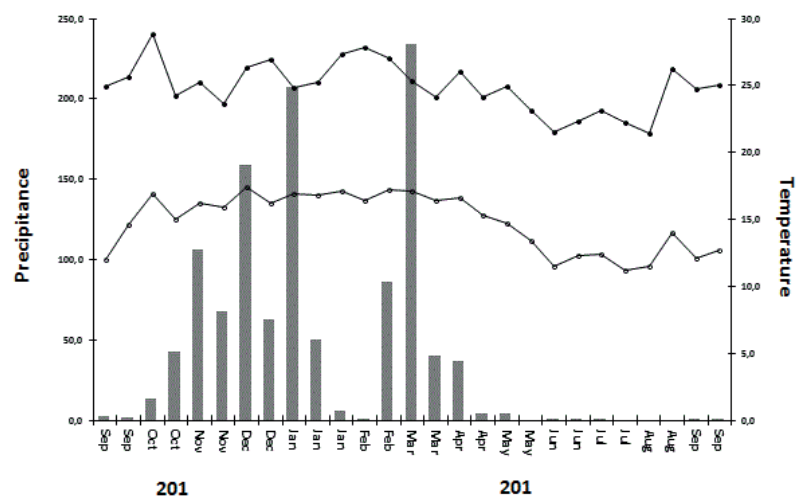

FIGURE I Values for precipitation (vertical bars) and maximum temperature (- - -) and minimum temperature (- - -) for the period of September/2010 to September/20II, wherein the phenology of Baccharis platypoda DC populations was observed. located in three areas of rupestrian grassland, Diamantina, Minas Gerais.

\section{Studied plant}

Baccharis platypoda DC. is a dioecious bush belonging the Asteraceae family, and is often found in rocky fields and altitude biomes in rocky outcrop or in hydromorphic fields with fertile soil. In the Cerrado, it is present in open fields, which occur in marshy areas, in sandy soils accumulated within rocks or in riparian forests (BORGES; FORZZA, 2008).

The individuals are between I and $2.5 \mathrm{~m}$ tall, and both genders present numerous inflorescences organized in chapters (BARROSO, 1976; BORGES; FORZZA, 2008). Female plants present apical glomerular chapters, and male plants present corymbiform chapters (BARROSO, 1976; BORGES; FORZZA, 2008); this characterizes a sexual dimorphism between male and female individuals during the reproductive period.

\section{Data collection}

The matrices of $B$. platypoda selected for the phenological analysis were composed of thirty individuals, fifteen of each gender. Botanic material from male and female individuals was prepared as witness, which was deposited at Herbário Dendrológico Jeanine Felfili (HDJF) from UFVJM, with registration number HDJF 964, HDJF 965 and HDJF 966.

The phenological observations happened from September/2010 to September/20II, with biweekly visits. The Fournier (1974) quantitative method was used for the flowering, fructification and leafage evaluation in several levels of development. For the flowering, the presence of flowering buds, immature flowers, mature flowers and concluded flowering were observed. The fructification was evaluated by means of the observation of immature, mature and dispersing fruits. The vegetative phenology was determined by the occurrence of leaf fall, the presence of mature leaves and budding.

\section{Climatic data}

In the period between September/2010 and September/20II, rainfall, temperature, humidity and insolation climatic data were given by the Estação Climatológica Principal de Diamantina (Diamantina Main Climatological Station) (18 $8^{\circ} 15^{\prime} \mathrm{S}, 43^{\circ} 36^{\prime} \mathrm{W}, 1296 \mathrm{~m}$ altitude), located about five kilometers from the study area.

\section{Data analysis}

The phenophases intensity observed was calculated through Fournier's index of intensity (1974), where the sum of the biweekly intensities was divided by the maximum possible value obtained by the number of sampled individuals multiplied by the higher intensity $(15 \times 4=60)$ and, afterwards, multiplied by 100 to obtain the percentage 
of each event intensity (BENCKE; MORELLATO, 2002). The relations between the vegetative and reproductive phenophases and the climatic factors intensities observed for each fortnight were tested acoording to Spearman's correlation $\left(r_{s}\right)$. The data were analyzed using the software STATISTICA, version 10 (STARSOFT, 20I2).

The most frequent period of each reproductive and vegetative phenophase during the phenology observation was calculated through the circular analysis, where the average angle and date was determined, indicating the occurrence period of a determined phenophase over the year (MORELLATO et al., 2000). The seasonality of the phenological events was determined by the test of Rayleigh ( $Z$ ) and the coefficient $r$, to verify the concentration of the events in each period, indicating the seasonality level (TALORA; MORELLATO, 2000; MORELLATO et al., 2000). If the $Z$ test has showed significant values $(p<0.05)$, the event has presented seasonality and the $r$ coefficient values indicated the seasonality level (MORELLATO et al., 2000). The circular analyses were performed on the ORIANA software, version 4.0I (KOVACK, 20II).

\section{RESULTS}

\section{Reproductive phenology}

The flowering buttons were observed from February to June, and there was a decline from May on which ended in mid of June. It was possible to notice that the male flowering buttons showed a higher peak of intensity at the beginning of the event in relation to the female buttons, which remained for a longer period (Figure 2A).

The occurrence of immature flowers has concentrated in the period of March to July for male individuals, from April to July for female individuals (Figure 2B). The female flowers have shown lower intensity, with briefer immature flowers occurrence in relation to the male ones, although there was a slight synchronism between the genders at the end of the event.

The presence of mature flowers in male and female individuals has occurred in distinct time intervals (Figure 2C). Male plants presented mature flowers between April and July, with peak in the mid of June. Female flowers had matured between May and October, keeping stability in the occurrence of phenophase between July and the beginning of September.

The flowering conclusion for male individuals began in May and ended in October, while female individuals' flowering was concluded from September on (Figure 2D). The male flowering concluded with higher intensity in July and declined from the second half of August on. The concluded flowering concentration occurred in different periods for both gender individuals.
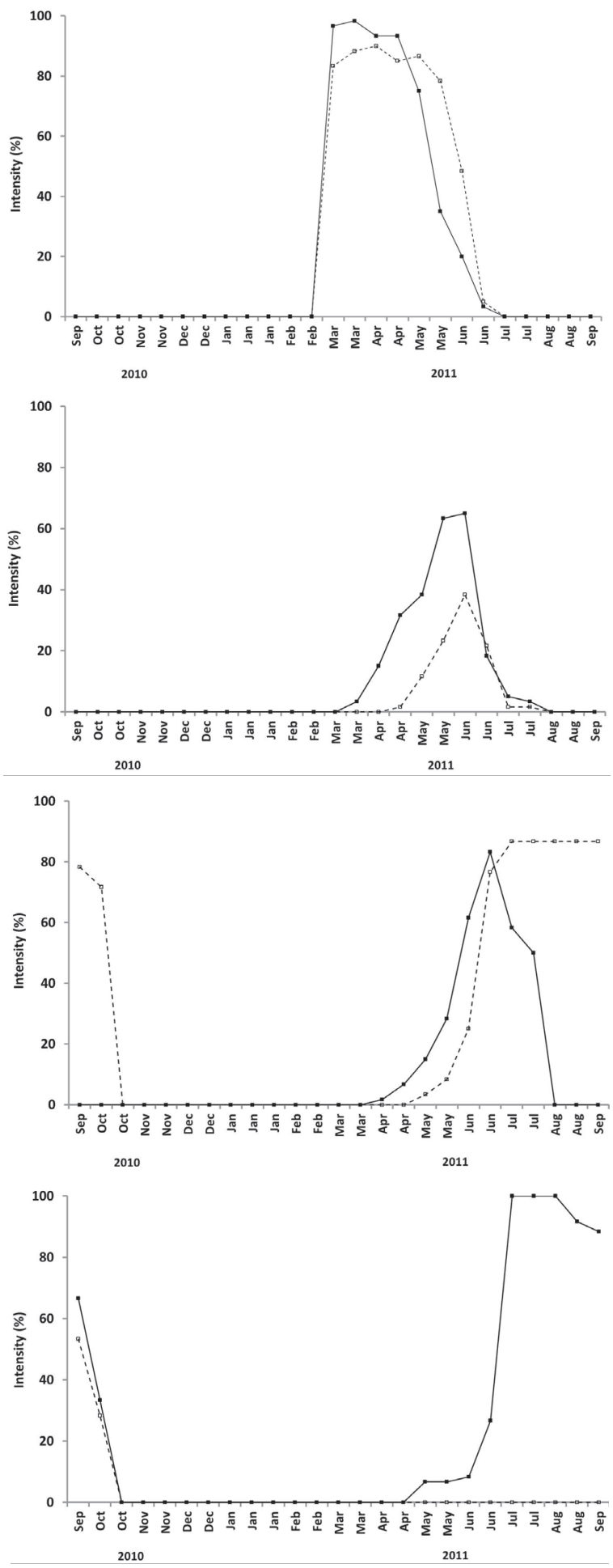

FIGURE 2 Intensities of the flowering phenology of male subjects (-•-) and females (-----) of Baccharis platypoda located in three areas of rupestrian grassland, Diamantina, Minas Gerais. The method of intensity Fournier, for abscission of floral buds (a), immature flowers (b), mature flowers (c) and completed flowering (d) was employed. The observation period of phenology was September/20I 0 to September/20II. 
The sampled plants have produced immature fruits between June and August, with peak of intensity at the beginning of July, declining afterwards (Figure 3A). Occurrence of mature fruits was observed between July and October, with maximum intensity at the beginning of August (Figure 3B). Dispersing fruits were noticed between July and October, with increase of intensity in September and October (Figure 3C).

The reproductive phenology has shown high seasonality level, determined by the $r$ and $Z$ test that were significant $(p \leq 0.05)$ (Table I). The circular analysis
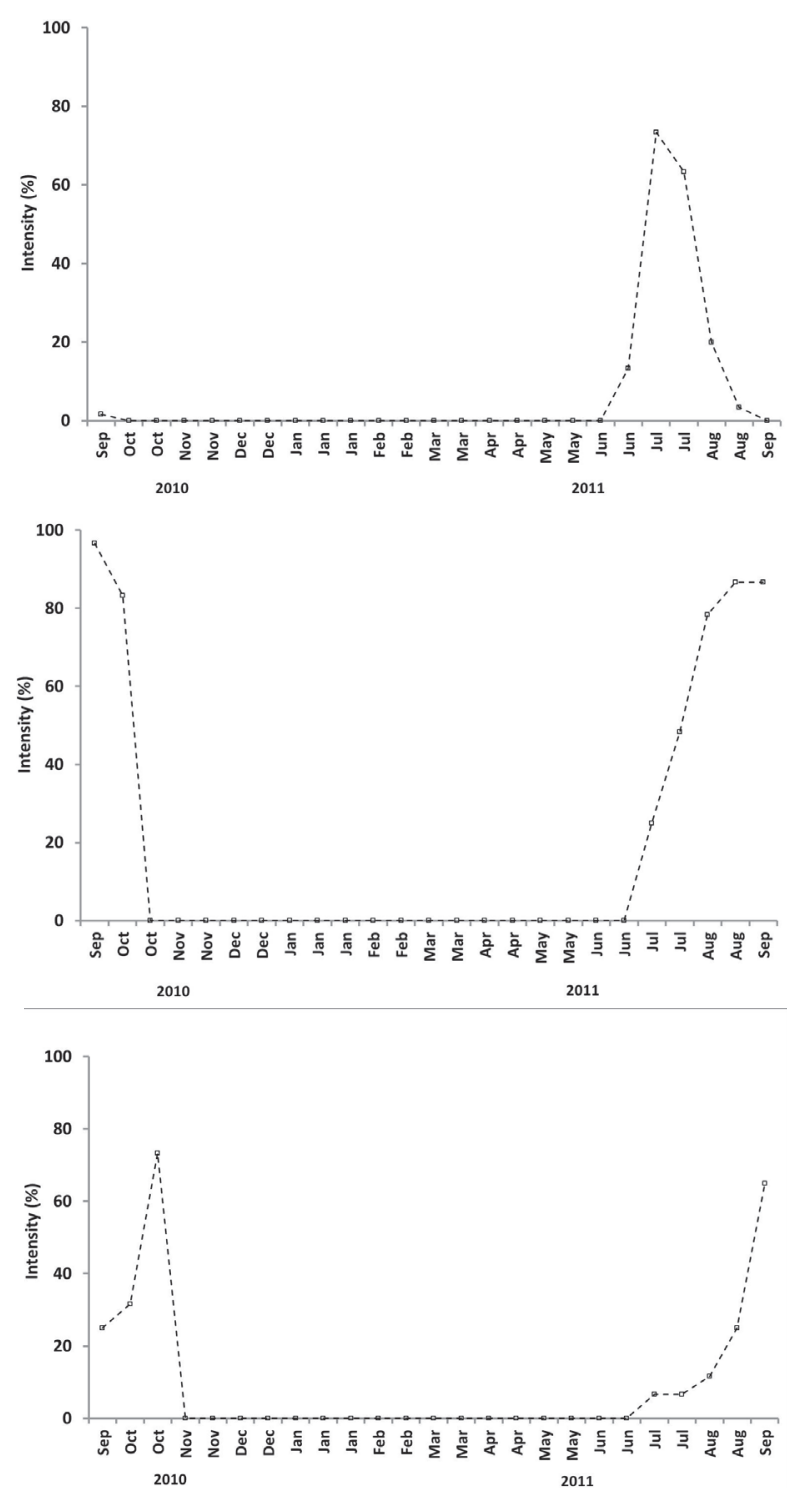

FIGURE 3 Intensities of fruiting phenophases of female individuals Baccharis platypoda located in three areas of rupestrian grassland, Diamantina, Minas Gerais. The method of intensity Fournier, for abscission of immature (a) fruits , ripe fruit (b), fruit dispersion (c) was employed. The observation period of phenology was September/2010 to September/201 I.
TABLE I Results of the circular analysis for the level of phenology seasonality of female $(q)$ and male individuals ( $\hat{0})$ of Baccharis platypoda, located at the margin of the Córrego Soberbo, Diamantina, Minas Gerais and sampled in the period of September/20I0 to September/20II. The analysis determined the average angle (MA) and the average date ( DM ) of occurrence of phenological events where: $r$ : coefficient of concentration, Z: Rayleigh test with $p \leq 0,05$.

\begin{tabular}{|c|c|c|c|c|c|}
\hline \multirow{2}{*}{ Phenophase } & \multicolumn{5}{|c|}{ Circular Analysis } \\
\hline & SEX & AM & DM & $r$ & Z \\
\hline \multicolumn{6}{|c|}{ Reproductive Phenophase } \\
\hline \multirow{2}{*}{ Fowering Buttons } & 우 & $200.788^{\circ}$ & $20, a p r$ & 0.908 & $465.495^{*}$ \\
\hline & $\hat{0}^{\lambda}$ & $194,119^{\circ}$ & 13, apr & 0.924 & 439.252* \\
\hline \multirow{2}{*}{ Immature Flowers } & 우 & $240,026^{\circ}$ & 30 , may & 0.96 & 93124* \\
\hline & $\hat{0}$ & $227.983^{\circ}$ & 19, may & 0.938 & $213081 *$ \\
\hline \multirow{2}{*}{ Mature Flowers } & 웅 & $308,309^{\circ}$ & 07 , aug & 0.78 & $425108^{*}$ \\
\hline & 0 & $256.689^{\circ}$ & 16 , jun & 0.926 & $26 \mid 426 *$ \\
\hline Flowering & क्ष & $3.406^{\circ}$ & 02 , oct & 0.997 & 80458* \\
\hline Conclusion & 0 & $307,852^{\circ}$ & 07 , aug & 0.829 & 432788* \\
\hline Immature Fruits & 오 & $282.758^{\circ}$ & $\mathrm{II}$, jul & 0.972 & $\left.164.33\right|^{*}$ \\
\hline Mature Fruits & 오 & $330.686^{\circ}$ & 30 , aug & 0.864 & $376.911 *$ \\
\hline \multirow[t]{2}{*}{ Dispersing Fruits } & 오 & $352.118^{\circ}$ & 22, sep & 0.867 & $185.075^{*}$ \\
\hline & Veg & etative Phe & ophase & & \\
\hline Budding & 앙 & $\begin{array}{l}346.286^{\circ} \\
310.547^{\circ}\end{array}$ & $\begin{array}{l}\text { 13, sep } \\
09 \text {, aug }\end{array}$ & $\begin{array}{c}0.26 \\
0.615\end{array}$ & $\begin{array}{c}21.6 * \\
233.451 *\end{array}$ \\
\hline \multirow{2}{*}{ Mature Leaves } & 웅 & $150,877^{\circ}$ & $03, \mathrm{mar}$ & 0.093 & $|8,50|^{*}$ \\
\hline & $0^{2}$ & $172,853^{\circ}$ & 23 mar & 0,096 & $20,835 *$ \\
\hline \multirow{2}{*}{ Leaf Fall } & $\begin{array}{l}9 \\
9 \\
9\end{array}$ & $254,361^{\circ}$ & 13, jun & 0.207 & $24,5 \mid 2 *$ \\
\hline & $\theta^{2}$ & $248.649^{\circ}$ & 09 , jun & 0.183 & $16,877^{*}$ \\
\hline
\end{tabular}

has indicated the month of April as average date for the formation of floral buttons; May for immature flowers. The mature flowers have presented average date of occurrence in June for male plants, and August for female plants. The species has presented August as average date for the conclusion of male flowering and October for the female flowering. As for fruits, the species has presented July as average date for the occurrence of the immature fruits, followed by August for mature fruits, and September for the dispersing fruits.

The phenophases of immature flowers of male and female plants have presented negative correlation with the rainfall, insolation, and maximum and minimum temperatures climatic variables, while the female immature flowers have presented positive correlation with the average temperature and, the male ones, negative correlation (Table 2). Male and female mature flowers have presented negative correlation with rainfall and maximum and minimum temperatures, being that for the average temperature there was positive correlation. The mature male flowers have also presented negative correlation with the insolation and the mature female flowers, positive correlation with the temperature amplitude. Only the completed flowering of male plants has presented significant correlation among rainfall, temperature and temperature amplitude. 
TABLE 2 Spearman correlation coefficients ( $r s$ ) between the vegetative and reproductive phenophases of Baccharis platypoda and environmental variables of precipitation (PP), humidity (A), sunshine (IN), maximum (TMAX), minimum (TMIN) and average (TMED) temperatures and temperature range (TA) for the period of September/2010 to September/20II. The values were estimated for male $(\hat{O})$ and female $(\not)$ individuals separately sampled near the edge of Córrego Soberbo, Diamantina, Minas Gerais.

\begin{tabular}{|c|c|c|c|c|c|c|c|c|}
\hline $\begin{array}{l}\text { Reproductive } \\
\text { Phenophase }\end{array}$ & SEX & PP & UM & IN & $x$ & V & $\mathrm{T}$ & AT \\
\hline \multicolumn{9}{|c|}{ Flowering } \\
\hline Fow & q & -0.06 & -0.18 & -0.15 & -0.27 & -0.04 & -0.16 & -0.35 \\
\hline Buttons & $0^{\lambda}$ & -0.02 & -0.21 & -0.09 & -0.28 & -0.02 & -0.16 & -0.39 \\
\hline Imma & 우 & $-0.55^{*}$ & 0.39 & $-0.59 *$ & $-0.6 I^{*}$ & * $-0.58 *$ & $0.63^{*}$ & 0.10 \\
\hline & $0^{\lambda}$ & $-0.46^{*}$ & 0.17 & $-0.50 *$ & $-0.56 *$ & -0.46 & $-0.52^{*}$ & -0.06 \\
\hline Mature & 우 & $-0.80^{*}$ & 0.36 & -0.31 & $-0.4 I^{*}$ & $-0.77 *$ & $0.62^{*}$ & $0.67 *$ \\
\hline Flowers & $\widehat{0}$ & $-0.54 *$ & 0.28 & $-0.56^{*}$ & $-0.58 *$ & -0.56 & $0.60 *$ & 0.11 \\
\hline Flowe & 우 & -0.04 & -0.31 & -0.33 & -0.32 & 0.07 & 0.23 & 0.37 \\
\hline & $\widehat{0}$ & * & 0.39 & -0.34 & $-0.42 *$ & $-0.76 *$ & |* & $0.65 *$ \\
\hline \multicolumn{9}{|c|}{ Fruit Set } \\
\hline $\begin{array}{l}\mathrm{Imn} \\
\mathrm{Fr}\end{array}$ & 우 & $-0.65^{*}$ & 0.28 & -0.24 & $-0.4 I^{*}$ & $-0.62 *$ & $-0.55^{*}$ & $0.4 I^{*}$ \\
\hline $\mathrm{Mat}$ & ㅇ & * & 0.18 & -0.09 & -0.04 & $-0.46 *$ & -0.26 & $0.67 *$ \\
\hline $\begin{array}{c}\text { Dispersing } \\
\text { Fruits }\end{array}$ & 우 & $-0.40 *$ & 0.21 & -0.12 & -0.07 & $-0.44 *$ & -0.29 & 0.56 \\
\hline \multicolumn{9}{|c|}{ Vegetative Phenophase } \\
\hline \multirow{2}{*}{ Budding } & q & -0.12 & 0.16 & -0.27 & 0.01 & -0.23 & $-0.12^{*}$ & 0.30 \\
\hline & $\widehat{0}$ & $-0.61^{*}$ & 0.27 & -0.19 & -0.38 & $-0.68 *$ & $-0.58 *$ & 0.54 \\
\hline & 우 & $-0.80 *$ & -0.36 & -0.31 & $-0.4 I^{*}$ & $-0.77 *$ & 0.28 & $0.67 *$ \\
\hline & $\widehat{0}$ & -0.17 & 0.16 & -0.16 & $-0.5 I^{*}$ & -0.25 & $-0.4 I^{*}$ & -0.37 \\
\hline \multirow{2}{*}{ Leaf Fall } & 우 & $-0.44 *$ & 0.06 & -0.22 & -0.33 & $-0.46 *$ & $-0.42^{*}$ & 0.14 \\
\hline & $\widehat{0}$ & -0.35 & 0.02 & -0.17 & $-0.50 *$ & $-0.46 *$ & $-0.50 *$ & -0.01 \\
\hline
\end{tabular}

* significative for $\mathrm{p} \leq 0,05$.

The phenology of immature fruits has presented negative correlation with the rainfall and temperature climatic variables, and for the temperature amplitude, it showed a positive correlation (Table 2). Mature and dispersing fruits showed negative correlation with the rainfall and minimum temperature and positive correlation with temperature amplitude.

\section{Vegetative phenology}

The budding occurrence has shown low intensity levels, with little variation from November to April, and the intensity decline was from October on (Figure 4A). For male plants, there was an intensity increase from May on, unlike the female plants, which showed a slight intensity increase between April and July and afterwards in August.
The presence of mature leaves was observed over all the period of study, with intensity levels over $48 \%$, both to the female and male plants (Figure 4B). Male plants have shown maximum intensity for the mature leaves in January, April and August. Female plants have shown the phenophase with higher intensity in the end of January and between July and August. Both female and male plants have presented an increasing standard in that phenophase intensity between October and November.

The leaf fall occurred for both genders, in low intensity, during all the period of phenology observation, and between February and July there was a phenophase intensity increase for female plants and stability for the male plants (Figure 4C). In the end of December and beginning of January, the presence of leaf fall for both genders was not observed.
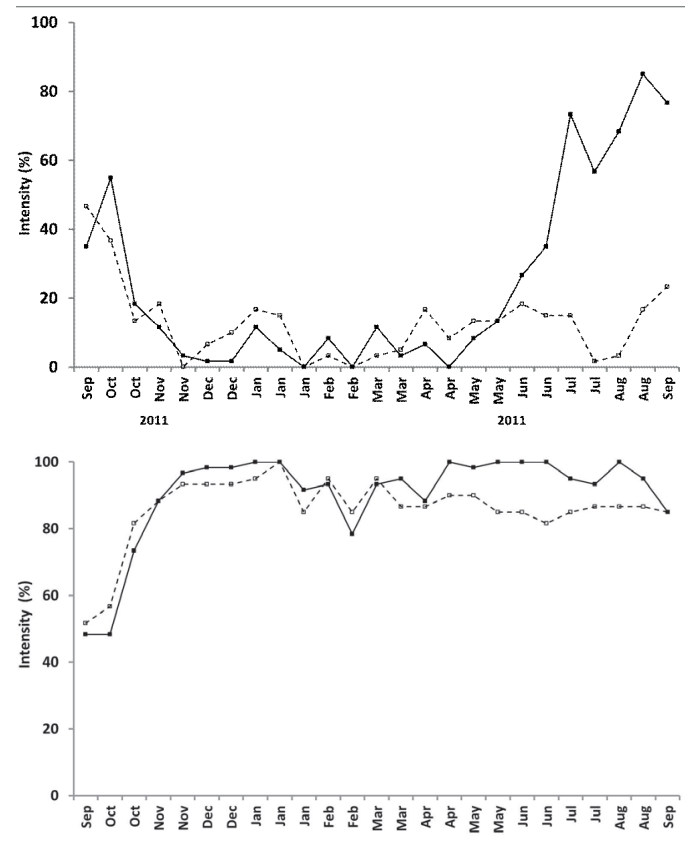

2010

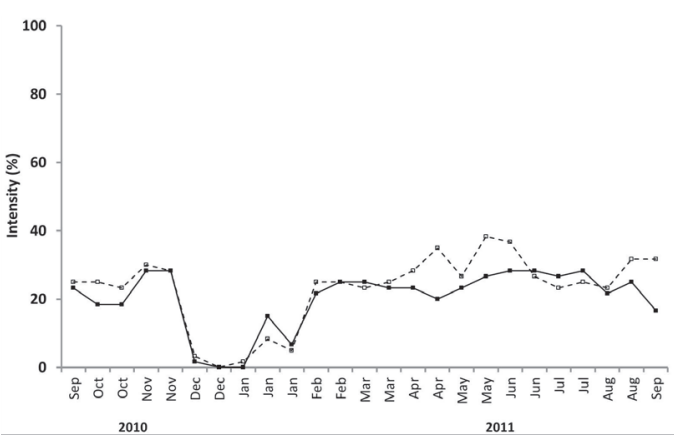

FIGURE 4 Intensities of the vegetative phenology of female individuals (-----) Baccharis platypoda located in three areas of rupestrian grassland, Diamantina, Minas Gerais. The method of intensity Fournier for phenophases budding (a), mature leaves (b) and leaf fall (c) was employed. The observation period of phenology was September/20 I 0 to September/20 I I. 
The circular analysis determined that the vegetative phenophases of the plants of both genders had shown seasonal standard (significant $z$ test for $p<0.05 \%$ ), but with low levels of seasonality determined by the $r$ test (Table I). The budding occurrence for the male plants had August as average date, while the female plants had September as average date for this phenophase. The mature leaves phenophase had average date in April and the leaf fall had June as average date for both genders.

For the budding of female plants, there was correlation only for the average temperature (Table 2). And the budding phenology of male plants had correlation with the rainfall, minimum and average temperature and positive correlation with the temperature amplitude. The occurrence of female mature leaves showed negative correlation with the rainfall, maximum and minimum temperature and positive correlation with the temperature amplitude, while the male plants showed negative correlation in mature leaves with the maximum and average temperatures. The plants of both genders showed negative correlation with the maximum and minimum temperatures. However, for the female leaf fall, there was negative correlation with the rainfall, and for the male leaf fall, negative correlation with the maximum temperature.

\section{DISCUSSION}

\section{Reproductive phenology}

It was possible to observe a low synchronism among some phenophases of the studied plant, and it was highlighted for other species of the genre Baccharis (ESPÍRITO-SANTO et al., 2003). The species demonstrated that there is a dependence on the rainfall and temperature for the occurrence of the reproductive events, although it does not point any dependence on the studied abiotic variables to initiate the emission of floral buttons. In vegetal species, the beginning of the reproductive period is associated to mechanisms that grant the appearing of flowers in favorable environmental conditions, and it can be associated to seeds dormancy processes (TOOKE; BATTEY, 2010) and to the high availability of nutrients accumulated in reserves by each plant, ensuring the reproduction under adverse conditions such as low water availability (SINGH; KUSHWAHA, 2006; CHAURASIA; SHUKLA, 2016). However, Oliveira (2008) states that only the dispersion phase associated with seed establishment is dependent on weather conditions, determining the temporal distribution of the remaining phenophases.
In the study period, the species showed only one reproductive cycle over the year, and that is the observed standard for the arboreal species from the Cerrado (PIRANI et al., 2009) and rupestrian grassland (CONCEIÇÃO et al., 2007; BELO et al., 20l3) as dioecious species (OTÁROLA et al., 2013; BENEVIDES et al., 2015). Thus, the species showed a certain dependence on favorable weather conditions in specific periods, like the low humidity, to initiate the seeds dispersion or the increase in the humidity to facilitate the germination and fixation of the seed. The flowering for some species can be related to the average temperature, and this abiotic variable is determining in the emission of flowering buttons and flowers maintenance in anthesis (TOOKE; BATTEY, 20I0; TORRES; GALETTO, 20I I).

The flowering cycle presented by B. platypoda in the study was considerably long (nearly eight months). This shows that a long flowering tends to be a standard for the dioecious species (FORERO-MONTAÑA; ZIMMERMAN, 20I0; OTÁROLA et al., 20I3; BENEVIDES et al., 20I5), with the beginning of the cycle during the rainy period and flowering conclusion with the end of the dry season (BULLOCK; BAWA, 198I; BULLOCK et al., 1983; CHAURASIA; SHUKLA, 2016). Kochmer and Handel (1986) noticed an average flowering time of eight months (including for the Asteraceae species), while Otárola et al. (2013) observed a flowering period for 10 months in Virola specie, what justified the long flowering period of B. platypoda. One flowering at the end of the rainy season grants a higher concentration of humidity necessary for the flower buttons formation and, because it extends to the dry period, it grants conditions for the flowering conclusion, fruits maturation and dispersion (REYS et al., 2005), indicating that the flowering time is strictly related to the great period for fruit dispersion (TORRES; GALETTO, $20 \mathrm{II}$ ). Species from Cerrado tends to initiate the flowering cycle in the end of the humid season and beginning of the dry season, with low humidity level (TANNUS et al., 2006; PIRANI et al., 2009), the same being observed for species of rupestrian fields (BELO et al., 2013). The standard also occurs for other dioecious species which presented flowering in the humid season (LENZA; OLIVEIRA, 2005; BENEVIDES et al., 20I5). Thus, female and male plants depend on higher humidity and temperature in the initial stage of the sexual organs formation and less humidity and temperature in the production of gamete production and release of chick-pollen, which will ensure pollination and seed formation.

The reproductive strategy presented by $B$. platypoda during the study has demonstrated that there 
is need for a major time interval, since it presented a long flowering period. The longer flowering time is often associated to a lower plant flower concentration, while species with shorter flowering periods have shown a higher concentration (TORRES; GALETTO, 20II). In dioecious species a big exposition of male flowers and the chick-pollen is related to the increase in the flowering time (BULLOCK; BAWA, 198I; MUNGUIAROSAS et al., 20II), thus increasing the pollination capacity (QUEENBOROUGH et al., 20 I3; MATSUHISA; USHIMARU, 20I5), while females only need the period necessary to receive the pollen grain to ensure the production of seeds (OTÁROLA et al., 20I3), presenting shorter and more intense capacity (MATSUHISA; USHIMARU, 2015)

The flowering in dioecious individuals tends to present distinct occurrence time between male plants and female plants (MUNGUIA-ROSAS et al., 201 I; MATSUHISA; USHIMARU, 20I5). The female flowering is delayed and synchronized with the peak intensity of male plants and an earlier male flowering was associated with the competition among individuals of the population for greater dispersal of gametes and consequently, their characters (BULLOCK; BAWA, 198I; GRANT, 1995; MUNGUIA-ROSAS et al., 20II; QUEENBOROUGH et al., 20I3; MATSUHISA; USHIMARU, 20I5). Female flowers support longer flowering cycle, maintaining a longer lasting bloom in relation to male flowering (ESPÍRITO-SANTO et al., 2003; MATSUHISA; USHIMARU, 2015), explained by the need for longer visits by pollinators. However, the male plants maintain immature and mature flowers for longer, ensuring an increase in the grain-of-pollen flow (BAWA, 1980).

The fruiting period occurred during the dry season (approximately five months), facilitating the dispersion of seeds, confirmed by completion of abscission of fruiting along with the beginning of the rainy season. In areas of rocky fields, the species have a fruiting pattern that ensures the wind by seed dispersal, occurring in periods of dry weather or dry to wet transition (ROCHA et al., 2016). Thus, $B$. platypoda presented a pattern similar to that observed for anemocoric species occurring in rock field areas. This pattern is also observed for Cerrado species, with the release of wind dispersed seeds during the dry season (BATALHA et al., 1997; LENZA; KLINK, 2006). The release seeds during the rainy season promotes germination and seedling development, the greater availability of water and nutrients in the soil (SINGH; KUSHWAHA, 2006; OLIVEIRA, 2008; PIRANI et al., 2009).
Anemochoric species depend directly on the strength and frequency of winds to release seeds (CONCEIÇÃO et al., 2007) and therefore depend on the driest season and greater occurrence of winds. The fruiting of anemochoric species tends to have a negative correlation with rainfall and a positive one with average temperature (TALORA; MORELLATO, 2000; PIRANI et al., 2009; NUNES et al., 2012), allowing the wind dispersed seeds to lose moisture and become lighter to be scattered by the winds (BATALHA et al., 1997). In areas of rupestrian fields, this is a significant adaptation because it allows dispersion of seeds to areas farther away from the mother plant, avoiding competition among young individuals and consequently the greater geographical occupation with greater chances of survival of the species (CONCEIÇÃO et al., 2007). The seeds of B. platypoda showed feathery structures that facilitated the dispersal by wind during dry periods, distending completely when the environment humidity is low (BARROSO, 1986).

\section{Vegetative phenology}

Species with vegetative growth throughout the year are associated with carbon assimilation during all seasons of the year (OLIVEIRA, 2008), and can be seen as an adaptive to competition or the use of available niches strategy (SEGHIERI et al., 20I2). The vegetative cycle of the species studied showed patterns of evergreen plant with continuous renewal of foliage throughout the year and at low intensity. Elements that restrict the production of biomass (stress) can interfere with the intensity of vegetative phenology of species occurring in severe environments (alpine pastures), helping the vegetative species have evergreen standard (AL-MUFTI et al., 1977). However, vegetative pattern of evergreen species to savannas is an adaptation to drought and is considered drought resistant species (SEGHIERI et al., 2012). This pattern tends to have a positive correlation with temperature for the production of leaves and a negative correlation with rainfall and average temperature for the leaves to fall (TALORA; MORELLATO, 2000; AMORIM; OLIVEIRA, 2006). Pirani et al. (2009) found a $20 \%$ share of Cerrado species with evergreen pattern, with continuous renewal of foliage. Thus, B. platypoda showed the same pattern observed for Cerrado.

The budding showed an increase in intensity during the dry season, as well as the phenology of leaf fall, with both maintaining a low intensity during the rainy season and a drop in intensity coinciding with the end of the dispersion and start of new phenological cycle. For 
dioecious species, the increase of the intensity of budding in the dry season in male plants in relation to the female ones and the coincidence with the production of fruits was reported by Amorim and Oliveira (2006). However, Espírito-Santo et al. (2012) observed that Baccharis retusa $\mathrm{DC}$. showed budding during the dry season, while Baccharis dracunculifolia DC. and Baccharis concinna G.M. presented vegetative growth during the rainy season.

Female individuals tend to allocate resources during the breeding season for flowering and fruiting, decreasing rates of vegetative growth (ESPÍRITO-SANTO et al., 2003) and justifying the decrease in intensity of budding and formation of new leaves for females of $B$. platypoda. For male plants, the reproductive cycle is shorter for not dispersing funds for the production and maturation of seeds, allowing a significant increase in the intensity of vegetative phenophases (GRANT, 1995).

\section{CONCLUSIONS}

The species $B$. platypoda showed small variations in phenological strategies of male and female individuals, especially the duration of reproductive phenophases and vegetative growth for resource allocation. Male and female individuals showed variations in the timing of phenology of both genders, with male individuals flowering earlier and longer than female subjects. The reproductive phenology of the species was associated with some environmental variables (precipitation and temperature), especially for fruiting phenophases, while the vegetative phenology, in general, was more associated with the reproductive phenology of species.

\section{ACKNOWLEDGMENT}

To the National Meteorology Institute (INMET), for conceding the weather data used in this work.

\section{REFERENCES}

AL-MUFTI, M. M.; SYDES, C. L.; FURNESS, S. B.; GRIME, J. P.; BAND, S. R. A quantitative analysis of shoot phenology and dominance in herbaceous vegetation. Journal of Ecology, v. 65 , p. $759-791$, 1977.

ALVES, R. J. V.; SILVA, N. G.; OLIVEIRA, J. A.; MEDEIROS, D. Circumscribing campo rupestre - megadiverse Brazilian rocky montane savannas. Brazilian Journal Biology, v. 74, p. 355-362, 2014.

AMORIM, F. W.; OLIVEIRA, P. E. Estrutura sexual e ecologia reprodutiva de Amaioua guianensis Aubl. (Rubiaceae), uma espécie dióica de formações florais de cerrado. Revista Brasileira Botânica, v. 29, p. 353-362, 2006.
BARROSO, G. M. Compositae - Subtribo Baccharidinae Hoffmann. Estudo das espécies ocorrentes no Brasil. Rodriguésia, v. 40, p. I-28I, 1976.

BARROSO, G. M. 1986. Sistemática de Angiospermas do Brasil, vol. 3. Viçosa, UFV.

BATALHA, M. A.; ARAGAKI, S.; MANTOVANI, W. Variações fenológicas das espécies do cerrado em Emas (Pirassununga, SP). Acta Botânica Brasilica, v. I I, p. 6I-78, 1997.

BAWA, K. S. Evolution of dioecy in flowering plants. Annual Review of Ecology and Systematics, v. I I, p. 15-39, 1980.

BAWA, K. S. Plant-pollinator interactions in tropical rain forests. Annual Review of Ecology and Systematics, v. 2I, p. 399-422, 1990.

BELO, R. M.; NEGREIROS, D.; FERNANDES, G. W.; SILVEIRA, F. A. O.; RANIERI, B. D.; MORELLATO, P. C. Fenologia reprodutiva e vegetativa de arbustos endêmicos de campo rupestre na Serra do Cipó, Sudeste do Brasil. Rodriguésia, v. 64, p. $817-828,2013$.

BENCKE, C. S. C.; MORELLATO, L. P. C. Comparação de dois métodos de avaliação da fenologia de plantas, sua interpretação e representação. Revista Brasileira Botânica, v. 25, p. 269-275, 2002.

BENEVIDES, C. R.; RODARTE, A. T. A.; LIMA, H. A. Strategies of flowering in dioecious plants in tropical coastal vegetation. Brazilian Journal of Botany, v. 38, p. 585-595, 2015.

BORGES, R. A. X.; FORZZA, R. C. A tribo Astereae (Asteraceae) no Parque Estadual do Ibitipoca, Minas Gerais, Brasil. Boletim de Botânica, v. 26, p. |3|-|54, 2008.

BORGES, R. A. X., CARNEIRO, M. A. A.; VIANA, P. L. Altitudinal distribution and species richness of herbaceous plants in campos rupestres of the Southern Espinhaço Range, Minas Gerais, Brazil. Rodriguésia, v. 62, p. 139-152, 201 I.

BULLOCK, S. H.; BAWA, K. S. Sexual dimorphism and the annual flowering pattern in Jacaratia dolichaula (D. Smith) Woodson (Caricaceae) in a Costa Rican Rain Forest. Ecology, v. 62, p. 1494-1504, 198 I.

BULLOCK, S. H.; BEACH, J. H.; BAWA, K. S. Episodic flowering and sexual dimorphism in Guarea rhopalocarpa in a Costa Rican Rain Forest. Ecology, v. 64, p. 85I-86I, 1983.

CONCEIÇÃO, A. A.; PIRANI, J. R.; MEIRELLES, S. T. Floristic, structure and soil of insular vegetation in four quartzite-sandstone outcrops of "Chapada Diamantina", Northeast Brazil. Revista Brasileira de Botânica, v. 30, p. $64 I-656,2007 b$.

CONCEIÇÃO, A. A.; FUNCH, L. S.; PIRANI, J. R. Reproductive phenology, pollination and seed dispersal syndromes on sandstone outcrop vegetation in the "Chapada Diamantina", northeastern Brazil: population and community analyses. Revista Brasileira de Botânica, v. 30, p. 475-485, 2007a. 
CHAURASIA, B.; SHUKLA, R. P. Changes in reproductive phenology and sex ratio of Trewia nudiflora Linn. Growing in sal Forest of North-eastern Uttar Pradesh, India. Tropical Ecology, v. 57, p. 89-99, 2016.

DIAS, H. C. T.; OLIVEIRA-FILHO, A. T. Fenologia de quatro espécies arbóreas de uma Floresta Estacional Semidecídua Montana em Lavras, MG. Ver. Cerne, v. 2, p. 66-88, 1996.

ESPÍRITO-SANTO, M. M.; MADEIRA, B. G.; NEVES, F. S.; FARIA, M. L.; FAGUNDES, M.; FERNANDES, G. W. Sexual differences in reproductive phenology and their consequences for the demography of Baccharis dracunculifolia (Asteraceae), a dioecious tropical shrub. Annals of Botany, v. 91, p. 13-19, 2003.

ESPÍRITO-SANTO, M. M.; NEVES, F. S.; FERNANDES, G. W.; SILVA. J. O. Plant phenology and absence of sex-biased gall attack on three species of Baccharis. Plos One, v. 7, p. I-10, 2012 .

FERNANDES, G. W. The megadiverse rupestrian grassland. In: FERNANDES, G. W. (ed.) Ecology and Conservation of Mountaintop Grassland in Brazil. Springer International Publishing. 2016. p. 3-I4.

FERNANDES, G. W.; BARBOSA, N. P. U.; NEGREIROS, D.; PAGLIA, A. P. Challenges for the conservation of vanishing megadiverse rupestrian grasslands. Natureza \& Conservação, v. 12, p. 162-165, 2014.

FORERO-MONTAÑA, J.; ZIMMERMAN, J. K. Sexual dimorphism in the timing of flowering in two dioecious trees in a subtropical wet Forest, Puerto Rico. Caribbean Journal of Science, v. 46, p. 88-95, 2010.

FOURNIER, L. A. Un metodo cuantitativo para la medición de características fenológicas em arboles. Turrialba, v. 24, p. 422-423, 1974.

GRANT, V. Sexual selection in plants: pros and cons. Proceedings of the National Academy of Sciences, v. 92, p. I247-1250, 1995.

GASTAUER, M.; MESSIAS, M. C. T. B.; MEIRA NETO, J. A. A. Floristic composition, species richness and diversity of campo rupestre vegetation from the Itacolomi State Park, Minas Gerais, Brazil. Environment and Natural Resources Research, v. 2, p. II5-130, 2012.

KOCHMER, J. P.; HANDEL, S. N. Constraints and competition in the evolution of flowering phenology. Ecological Monographs, v. 56, p. 303-325, 1986.

KOVACH, W. L. Oriana for Windows, V.4 e. Anglesey, Wales, UK, Kovach Computing Services. 201 I

LENZA, E.; OLIVEIRA, P. E. Biologia reprodutiva e fenologia de Virola sebifera Aubl. (Myristicaceae) em mata mesofítica de Uberlândia, MG, Brasil. Revista Brasileira de Botânica, v. 29, p. 443-45I, 2006.
LENZA, E.; KLINK, C. A. Comportamento fenológico de espécies lenhosas em um cerrado sentido restrito de Brasília, DF. Revista Brasileira de Botânica, v. 29, p. 627638, 2006.

LENZA, E.; OLIVEIRA, P. E. Biologia reprodutiva de Tapirira guianensis Aubl. (Anacardiaceae), uma espécie dióica em mata de galeria do Triângulo Mineiro, Brasil. Revista Brasileira de Botânica, v. 28, p. I79-190, 2005.

LE STRADIC, S.; BUISSON, E.; FERNANDES, G. W. Vegetation composition and structure of some neotropical mountain grasslands in Brazil. Journal of Mountain Science, v. I2, p. 864-877, 2015.

MATSUHISA, S.; USHIMARU, A. Sexual dimorphism in floral longevity and flowering sunchrony in relation to pollination and mating success in three dioecious Ilex species. American Journal of Botany, v. 102, p. I-I I, 2015.

MATSUYAMA, S.; SAKIMOTO, M. Allocation to reproduction and relative reproductive costs in two species of dioecious Anacardiaceae with contrasting phenology. Annals of Botany, v. I0I, p. I39I-I400, 2008.

MESSIAS, M. C. T. B.; LEITE, M. G. P.; MEIRA NETO, J. A. A.; KOZOVITS, A. R.; TAVARES, R. Soil-vegetation relationship in quartzitic and ferruginous Brazilian rocky outcrops. Folia Geobotanica, v. 48, p. 509-521, 2013.

MESSIAS, M. C. T. B.; LEITE, M. G. P.; MEIRA NETO, J. A. A.; KOZOVITS, A. R. \& TAVARES, R. Life-form spectra os quartzite and itabirite rocky outcrop sites, Minas Gerais, Brazil. Biota Neotropica, v. I I, p. 255-268, 201 I.

MORELLATO, L. P. C.; TALORA, D. C.; TAKAHASI, A.; BENCKE, C. C.; ROMERA, E. C. \& ZIPPARRO, V. B. Phenology of atlantic rain forest trees: a comparative study. Biotropica, v. 32, p. 81 I-823, 2000.

MUNGUIA-ROSAS, M. A.; OLLERTON, J.; PARRA-TABLA, V. Phenotypic selection on flowering phenology and size in two dioecious plant species with different pollen vectors. Plant Species Biology, v. 26, p. 205-2I2, 201 I.

NEVES, S. C.; ABREU, P. A.; FRAGA, L. M. Fisiografia. In: SILVA, A. C.; PEDREIRA, L. C. V. S. F.; ABREU, P. A. A. (eds.). Serra do Espinhaço Meridional: paisagens e ambiente. O lutador, Belo Horizonte. 2005. p. 47-58.

NUNES, Y. R. F; LUZ, G. R.; BRAGA, L. L. Phenology of trees species populations in tropical dry forests of southeastern Brazil. In: ZHANG, X. (eds). Phenology and climate change. InTech. 20I2. p. I25-I42.

OLIVEIRA, P. E. A. M. Fenologia e biologia reprodutiva das espécies de cerrado In: SANO, S. M.; ALMEIDA, S. P. E.; RIBEIRO, J. F. (eds.). Cerrado: ecologia e flora - volume I. Embrapa Informações Tecnólogicas. 2008. p. 273-290.

OTÁROLA, M. F.; SAZIMA, M.; SOLFERINI, V. N. Tree size and its relationship with flowering phenology and reproductive output in Wild Nutmeg trees. Ecology and Evolution, v. 3, p. 3536-3544, 2013. 
PIRANI, F. R.; SANCHEZ, M.; PEDRON, I. F. Fenologia de uma comunidade arbórea em cerrado sentido restrito, Barra do Garças, MT, Brasil. Acta Botanica Brasilica, v. 23, p. |096-I 109, 2009.

QUEENBOROUGH, S. A.; HUMPHREYS, A. M.; VALENCIA, R. Sex-specific flowering patterns and demography of the understorey rain forest tree Iryanthera hostmannii (Myristicaceae). Tropical Conservation Science, v. 6, p. 637-652, 2013.

REYS, P.; GALETTI, M.; MORELLATO, L. P. C.; SABINO, J. Fenologia reprodutiva e disponibilidade de frutos de espécies arbóreas em mata ciliar no Rio Formoso, Mato Grosso do Sul. Biota Neotropica 5. 2005. Disponível em: http://www.biotaneotropica.org.br.

ROCHA, N. M. W. B.; CARSTENSEN, D. W.; FERNANDES, G. W.; LE STRADIC, S.; BUISSON, E.; MORELLATO, L. P. C. Phenology patterns across a rupestrian grassland altitudinal gradient. In: FERNANDES, G. W. (eds.) Ecology and Conservation of Mountaintop Grassland in Brazil. Springer International Publishing. 2016. p. 275-289.

SAKAI, A. K.; BURRIS, T. A. Growth in male and female aspen clones: a twenty-five-year longitudinal study. Ecology, v. 66, p. 1921-1927, 1985.

SEGHIERI, J.; DO, F. C.; DEVINEAU, J. L.; FOURNIER, A. Phenology of woody species along the climatic gradient in west tropical Africa. In: ZHANG, X. (ed), Phenology and climate change. InTech. 20I2. p. I43-I78.

SILVEIRA, F. A. O.; NEGREIROS, D.; BARBOS, A. N. P. U.; BUISSON, E.; CARMO, F. F.; CARSTENSEN, D. W.; CONCEIÇÃO, A. A.; CORNELISSEN, T. G.; ERHTERNACH, T. L.; FERNANDES, G. W.; GARCIA, Q. S.; GUERRA, T. J.; JACOBI, C. M.; LEMOS-FILHO, J. P.; LE STRADIC, S.; MORELLATO, L. P. C.; NEVES, F. S.; OLIVEIRA, R. S.; SCHAEFER, C. E.; VIANA, P. L.; LAMBERS, H. Ecology and evolution of plant diversity in the endangered campo rupestre: a neglected conservation priority. Plant and Soil, p. I43-I78, 2015.
SINGH, K. P.; KUSHWAHA, C. P. Diversity of flowering and fruiting phenology of trees in a Tropical Deciduous Forest in India. Annals of Botany, v. 97, p. 265-276, 2006.

STATSOFT INC. Electronic Statistics Textbook. Tulsa, OK: StatSoft. WEB: http://www.statsoft.com/textbook/. 2012

SUTHERLAND, S.; DELPH, L. F. On the importance of male fitness in plants: patterns of fruit-set. Ecology, v. 65, p. 1093-I 104, 1984.

TALORA, D. C.; MORELLATO, P. Fenologia de espécies arbóreas em floresta de planície litorânea do sudeste do Brasil. Revista Brasileira de Botânica, v. 23, p. 13-26, 2000.

TANNUS, J. L. S.; ASSIS, M. A.; MORELLATO, L. P. C. Fenologia reprodutiva em campo sujo e campo úmido numa área de cerrado no sudeste do Brasil, Itirapina SP. Biota Neotropica 6. Disponível em: http://www. biotaneotropica.org.br. 2006.

THOMAS, S. C.; LAFRANKIE, J. V. Sex, size and interyear variation in flowering among dioecious trees of the Malayan Rain Forest. Ecology, v. 74, p. 1529-1537, 1993.

TOOKE, F.; BATTEY, N. H. Temperate flowering phenology. Journal of Experimental Botany, v. 6I, p. 28532862, 2010.

TORRES, C.; GALETTO, L. Flowering phenology of cooccurring Asteraceae: a matter of climate, ecological interactions, plant attributes or of evolutionary relationships among species? Organisms Diversity \& Evolution, v. II, p. $9-19,2011$.

VASCONCELOS, M. F. O que são campos rupestres e campos de altitude nos topos de montanha do Leste do Brasil? Revista Brasileira de Botânica, v. 34, p. 24I-246, 20 II. 